\title{
Deer focus farms - are they working?
}

\author{
T.A. PAYNE ${ }^{1}$, D.R. STEVENS ${ }^{2}$ and M.J. CASEY ${ }^{3}$ \\ ${ }^{1}$ AgResearch Ltd., Ruakura Research Centre, Private Bag 3123, Hamilton, New Zealand \\ ${ }^{2}$ AgResearch Ltd., Invermay Research Centre, Private Bag 50034, Mosgiel, New Zealand \\ ${ }^{3} P G G$ Wrightson Consulting, Private Bag 1961, Dunedin, New Zealand \\ tracy.payne@agresearch.co.nz
}

\begin{abstract}
This study aimed to understand how farmers responded to field days and newsletters delivered in a Focus Farm project for deer farmers in Otago and Southland. In 2006, 30 deer farmers from Otago and Southland were interviewed on their environmental practices. Farmers were re-interviewed after 2 years to assess their involvement in the Focus Farm project and the value of that project to them. This project had a significant impact on both environmental and productivity improvements on the farms (averaging 2.2 and 1.1 changes per farm, respectively), both of farmers who attended the field days and those who only received newsletters (averaging total changes of 4.6 and 2.0 per farm, respectively). While the value of focus or monitor farms has been reported before, this research shows a clear benefit from associated newsletters that are circulated and provide information to farmers that may not be able to attend the field days, or be directly involved.
\end{abstract}

Keywords: deer farming, environmental, focus farms, field days, newsletters, productivity

\section{Introduction}

Deer farming is a relatively young and diverse industry in New Zealand. Research has established some best farming practices for deer (Casey 2003), yet the levels of uptake are extremely variable. Under modest product returns deer farmers need to become more efficient producers to compete with sheep and cattle for land use. Deer management practices which do not cater for the natural behaviour of deer can have a negative impact on the environment, especially soil and water quality (McDowell \& Stevens 2006). Overseas consumer concerns about the health and sustainability of deer farms make the development and uptake of sustainable land management practices vital.

Focus on Deer was a joint project between the Otago, Southland and Fiordland branches of the New Zealand Deer Farmers Association (NZDFA), PGG Wrightson Consulting and AgResearch Invermay and principally funded by the MAF Sustainable Farming Fund and the Foundation of Research, Science and Technology. Local farmers, regional councils, scientists, agribusiness and consultants were all part of a project which ran from
July 2005 to June 2008. The project provided a blend of demonstration and experimentation to enhance the uptake of production and environmental practices in the deer industry. The project was based on the Meat \& Wool NZ Monitor farm programme (McIvor \& Aspin 2001; Rhodes \& Aspin 1993), but was modified to include a much greater input of environmental practice and scientific demonstration and research.

The project also provided a high quality newsletter which updated farm activities, new research findings and reports from the field days for farmers who could not attend. The content of the newsletters was provided by the facilitating consultant, the researchers, field day contributors and the regional council staff. They were published three times per year to coincide with the three major meetings on the farms. The newsletters were mailed out to all levy paying deer farmers within the three NZDFA contributing areas.

The aim of this study was to understand how farmers responded to the Focus on Deer field days and newsletters in Otago and Southland. In 2006, 30 deer farmers throughout Otago and Southland were interviewed on their environmental practices. Two years later, these farmers were interviewed again to find out about their involvement with the deer focus farm project, and if so, what changes had they made to their farming system.

\section{Methods}

Fifteen deer farmers from Southland and 15 from Otago were interviewed in 2006 about their approach to deer farming factors, such as fence pacing, pugging, waterway fencing, wallowing management and wintering practices, that may impact on the environment (Payne \& White 2006b). Deer farmers were chosen from a recent list of levy payers in the two regions. Care was taken to interview across a range of deer farming types. After 2 years the same farmers were again interviewed to assess their involvement in the Focus on Deer project and the impact it may have had on their deer farming practices. The environmental practices that were promoted during the Focus on Deer project (Table 1) aimed to keep deer out of waterways or mitigate the effects on water quality, and to reduce soil damage. Many of these were actively researched 
Table 1

Environmental practices that were researched and demonstrated during the Focus on Deer project.

Waterway fencing to exclude stock

Providing safe wallows that were not connected to waterways

Planting shelter trees to reduce stress and lower fence pacing

Fencing hotspots of erosion and water contaminants

Providing recovery zones through riparian fencing and management

Developing nutrient budgets to minimise fertiliser use

Appropriate wintering management practices including grazing and crop utilisation plans.

during the project (McDowell 2009) and developed a sense of responsibility and ownership by the farming community as well as demonstrating the positive benefits of the practices. Productivity and profitability was also a feature of the project and were also assessed during the interview process.

Questions were based around the following topics:

1. General views of focus farm days

2. New fence pacing strategies

3. New pugging strategies

4. Number of trees

5. New wallowing strategies

6. Strategies towards waterway fencing

7. Improvements in productivity

8. Social aspect of the focus farm days

The interview responses were then used to analyse how the level of farmer involvement with the Focus on Deer project influenced the degree of technology implementation.

\section{Results and Discussion}

Focus farm field days were held three to four times a year. Numbers of farmers attending varied considerably, which was disappointing to many respondents. There was a perception by one respondent that when environmental issues were on the agenda less farmers attended.

The deer farmers were classified based on whether farmers were attending the Focus on Deer field days (Fig. 1) to allow some comparison of their uptake of the ideas presented through the project. Segment one farmers had never attended a focus farm field day as they did not believe there was anything for them to learn from the focus farm field days. Segment two included farmers who had never attended a focus farm field day but were constrained by distance, "driving to and from the host farm, including the meeting, would take all day. I don't have the time".

The third segment consisted of deer farmers who did attended the focus farm days regularly. Deer farmers in segment four had attended at least one focus farm day but did not regularly attend, "I live within an easy drive to the host farm but do not see the value in looking at the same farm many times".

\section{General views on deer focus farm field days}

The field days were considered by $100 \%$ of respondents to be beneficial for a range of reasons (Table 2). Farmers commented that "the concept is right".

The informal time of the focus farm field days was considered to be an essential component of the field day. While listening to 'experts' speak and viewing the changes of the host farm were considered important, the informal time was considered by many to be the

Figure 1 Typology of involvement of deer farmers in the Focus on Deer project.

Yes

No

Have you attended at least one Deer Farm Focus Day?

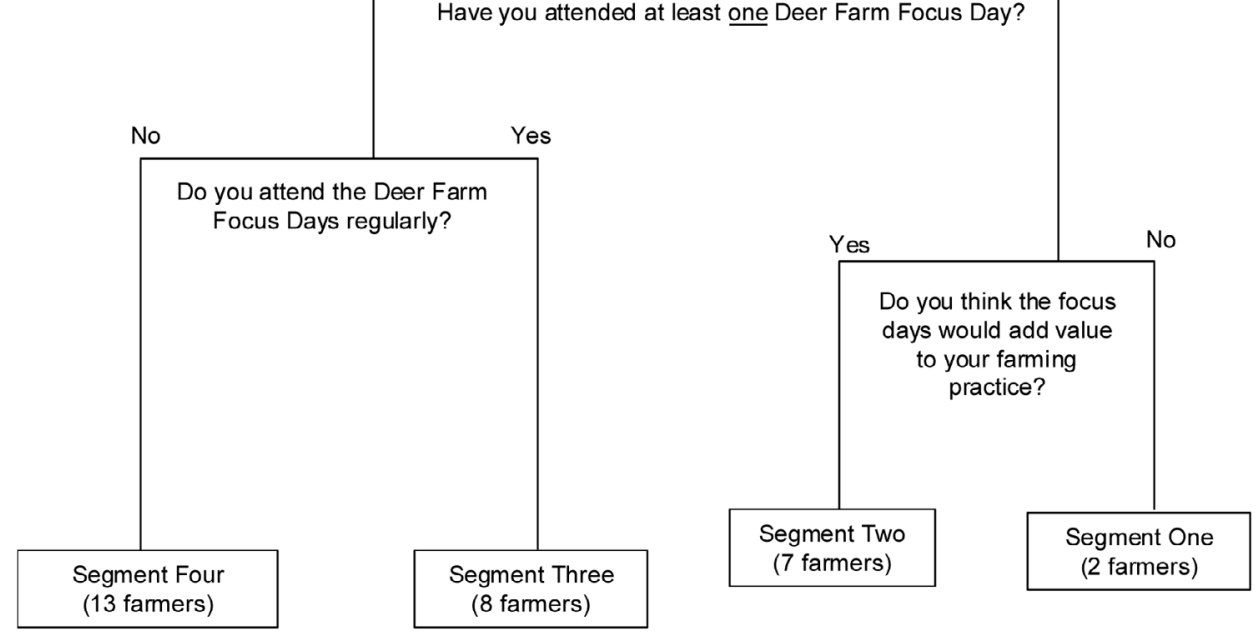


Table 2 Perceived benefits of attending the focus farm field days.

\begin{tabular}{lc}
\hline Perceived benefit & $\begin{array}{c}\text { Number of farmers } \\
\text { (\% in brackets) }\end{array}$ \\
\hline Seeing changes on the host farm & $19(91 \%)$ \\
Learning new ideas and practices & $14(67 \%)$ \\
See if 'experts' theories work & $15(71 \%)$ \\
on-farm before implementing them & $8(38 \%)$ \\
Listening to 'experts' ideas & $10(48 \%)$ \\
Finding out what's happening in & $21(100 \%)$ \\
the industry & \\
Talking to other farmers about their \\
farming system \\
Catching up with neighbours
\end{tabular}

most important part of the field day. This time was "key for the entire concept of running a focus farm". It was considered a good opportunity to interact with other farmers, as "farmers like to see other farmers". Farmers new to the district saw the focus farm day as a good chance to meet their neighbours and learn about specific farming issues for the area. The social time at the end of the focus farm day provided an opportunity to ask invited speakers questions, on a one-to-one basis, as opposed to asking a question out loud in front of a large group. This appealed for a third of respondents who did not always feel confident asking a question in front of others.

However, for others, although the focus farm field days were a good opportunity to talk with other deer farmers, the age of attendees was an issue as some found most of the farmers attending the days to be "closer to my Dad's age".

For farmers attending the field days, it was beneficial to listen to different people involved in the industry. Invited speakers ranged from scientists, industry representatives, regulatory authority representatives, farm advisors and farmers themselves. The Otago Regional Council was considered especially useful. This had surprised some respondents as their perception of the Council was previously a negative one.

\section{Deer Focus Farm newsletter}

Although farmers may not have attended every field day, every deer farmer in the Otago and Southland region received regular updates, via newsletter, about the host farms and the demonstrations and research that was being done. This was considered a useful source of information, especially for those farmers in segment two, who would like to attend the field days but could not do so. The Focus on Deer newsletters were an excellent way to communicate sustainable land use practices to a wide range of deer farmers. So, although the numbers attending the focus farm were not always high, the results from the host farms were reaching many others.

\section{Changes since 2006}

Of all deer farmers that had attended at least one field day 95\% (20 farmers) had made at least one change to their deer farming system as a result. The benefit of the field day for respondents was learning new ideas and practices then incorporating them into their specific farm context. As one farmer noted "different people have different ideas... can tweak it to your context". The majority of changes since the initial interviews were to farmer's environmental practices (Table 3). Overall, attendees were more aware of potential environmental issues.

Farmers who regularly attended the field days made more changes than those farmers who only read the newsletters (4.6 compared to 2.0 changes per farmer). Farmers who attended the field days occasionally made, on average, 3.2 changes. These findings (Table 3) demonstrate the impact that field days and newsletters have on the wider deer farming community.

Changes in management practices affecting soil damage and erosion included managements that reduced fence pacing and pugging, and increased tree planting. The two focus farms implemented strategies to decrease fence pacing and pugging such as reducing mob numbers, increasing nutrition and improved winter grazing management. The planting, and protecting, of trees to provide shade and shelter was also a key strategy. The two host farms were in the process of placing a QEII covenant on areas of their farms ${ }^{1}$. Respondents who attended the field days commented that listening to the reasons why a QEII covenant was adopted by the host farms was useful.

An average of $47 \%$ of respondents had planted more trees since 2006. This varied between the segments (Table 3). Attending the field days provided farmers with a chance to see what tree species the host farms had planted and to see how their progress was going. This was considered a useful tool as many farmers, in 2006, spoke of the trouble establishing trees.

In 2006 fence pacing was generally accepted as a process which occurs because the animals have not long been domesticated and occurs during times of stress. For farmers who had a problem with pacing in $2006,20 \%$ had made changes to their farming practice

1 "A QEll covenant is a legally binding protection agreement which is registered on the title of the land. It is voluntary but once in place binds the current and all subsequent landowners" (www.qe2.org.nz). 


\begin{tabular}{|c|c|c|c|c|}
\hline & $\begin{array}{c}\text { Segment } 3 \\
\text { (regularly attend) }\end{array}$ & $\begin{array}{c}\text { Segment } 4 \\
\text { (occasionally } \\
\text { attend) }\end{array}$ & $\begin{array}{c}\text { Segment } 2 \\
\text { (do not attend; } \\
\text { read the focus } \\
\text { farm newsletter) }\end{array}$ & $\begin{array}{c}\text { Total } \\
\text { (and \% of total) }\end{array}$ \\
\hline \multicolumn{5}{|c|}{ Management to reduce soil damage and loss } \\
\hline Reduced fence pacing & 2 & 4 & 0 & $6(20 \%)$ \\
\hline Reduced pugging & 4 & 1 & 0 & $5(17 \%)$ \\
\hline Tree planting & 6 & 4 & 4 & $14(47 \%)$ \\
\hline Total soil changes & $12(1.5)^{1}$ & $9(0.7)$ & $4(0.6)$ & \\
\hline \multicolumn{5}{|c|}{ Management to improve water quality } \\
\hline Wallow management & 5 & 8 & 0 & $13(43 \%)$ \\
\hline Waterway fencing & 7 & 10 & 5 & $22(73 \%)$ \\
\hline Total water changes & $13(1.6)^{1}$ & $18(1.4)$ & $5(0.7)$ & \\
\hline \multicolumn{5}{|c|}{ Managements to improve productivity } \\
\hline Wintering management & 4 & 6 & 3 & $13(43 \%)$ \\
\hline Feed management & 4 & 6 & 1 & $11(37 \%)$ \\
\hline Stock management & 4 & 3 & 1 & $8(27 \%)$ \\
\hline Total productivity changes & $12(1.5)^{1}$ & $15(1.2)$ & $5(0.7)$ & \\
\hline Total changes & $37(4.6)^{1}$ & $42(3.2)$ & $14(2.0)$ & \\
\hline No changes & 0 & 1 & 2 & $3(10 \%)$ \\
\hline
\end{tabular}

${ }^{1}$ average number of changes per farmer in brackets

since attending the field days. The most useful source of information was other farmers and viewing what the host farms had done to decrease the problem. There was still the belief that it would always be a problem when farming deer.

Changing managements to improve water quality included wallowing management and waterway fencing. The two focus farms had both increased their waterway fencing. In 200629 farmers had waterways running through their deer block. Farmers in 2006 indicated that due to the current economic climate they were unable to fence off all waterways at once (Payne \& White 2006a). Many farmers had strategies in place where they fenced off a set length of waterway each year. By 2008 a large majority (73\%) of farmers had increased the amount of waterway fencing.

Nearly half of all respondents had changed the way they managed wallows. Researchers had highlighted the problems caused by wallows (McDowell et al. 2006), but it was during the informal time whilst talking to other farmers where practical solutions arose. In 2006 farmers generally accepted wallowing as a natural part of deer behaviour. Two years on, while this view is still there, farmers noted that it was valuable talking with others farmers about the problems and solutions.

In 2006, farmers were not questioned on their productivity. Therefore, farmers were asked to comment on any improvements they had noticed, or changes they had made, since attending the field days. Specific changes farmers had made included:
- Wintering management

- Tips for handling animals

- How to manage stags

- Internal parasite management

Improvements in wintering management systems were noted by $43 \%$ of all respondents (Table 3 ). Farmers found talking with other farmers, listening to 'experts' and seeing what was happening on the host farm valuable. Farmers had changed how, and what, they fed their animals during wintering. Since changing their wintering practices, they had noticed an improvement in their spring pastures. Some farmers $(27 \%)$ had changed their stock management from information they had received from the field days. Once again, speaking with farmers and seeing the processes of the host farms had influenced this change.

\section{Recommendations}

Farmers were asked for suggestions to improve the focus farm field days as a critical aspect of the research. Overall the Deer Focus Farms were viewed as a valuable learning tool and the concept was considered right.

Recommendations from farmers who did not attend field days are critical to incorporate if organisers want the number of farmers attending to increase. These included:

- Have at least one focus farm field day not on-farm so other people can attend

- Make the focus farm more geographically central

- Continue the newsletters

- Improve the field day timing 
Deer farmers who attended regularly provided a wider understanding of the issues discussed. Suggested improvements included:

- Not enough notice given to when the field days are going to be held. However, the problem remains that if farmers are informed too far in advance they may forget, but if told too late they may have already organised things for that day

- Some of the speakers were disappointing, especially industry representatives

- Need speakers who "aren't selling a product"

- Not learning everything new, refining the "same old stuff"

- Need a "really good facilitator... key to success"

- Range of speakers needed "don't have to be from within the industry"

Less regular attendees had valuable feedback as to what improvements could be made for them to attend the field days more regularly. Suggestions included:

- More notice for field days and what the topics are

- Not all topics are relevant,

- Not always learning new, useful things

- Time is an issue, especially when you do not employ labour.

- "Gets a bit boring going to the same farm all the time"

- Ensure that new approaches and technologies are to the fore "don't want to hear the same old, same old... what new technologies are going to make us more profitable, more appealing to our markets?... that's want I want to hear at the field days".

\section{ACKNOWLEDGEMENTS}

The authors wish to thank Richard Copland, facilitator of the Focus on Deer project and to MAF Sustainable Farming Fund for financial support. A thank you must also go to the deer farmers who gave up their time to share their experiences with us.

\section{REFERENCES}

Casey, M.J. (Ed.) 2003. Deer Nutrition Symposium: The nutrition and management of deer on grazing systems. Grassland Research and Practice Series 9. $125 \mathrm{pp}$.

McDowell, R.W. 2009. Deer, soils and water. Proceedings of a Deer Course for Veterinarians 25: in press.

McDowell, R.W.; McGrouther, N.; Morgan, G.; Srinivasan, M.S.; Stevens, D.R.; Johnson, M.R.; Copland, R. 2006. Monitoring the impact of farm practices on water quality in the Otago and Southland deer focus farms. Proceedings of the New Zealand Grassland Association 68: 183-188.

McDowell, R.W.; Stevens, D.R. 2006. Experiments examining soil and water quality in a New Zealand deer farm. pp. 235-257. In: Focus on environmental research. Ed. Emma. B., Davis. Nova Science Publishers, Inc., New York.

McIvor, S.D.; Aspin, M.D. 2001. R\&D success stories and principles to practice. Proceedings of the New Zealand Grassland Association 63: 23-28.

Payne, T.; White, T. 2006a. Deer farmers attitudes to fencing waterways. Proceedings of the New Zealand Grassland Association 68: 189-192.

Payne, T.; White, T. 2006b. Understanding deer farmers level of environmental awareness. Client Report for MAF SFF 'Focus on deer'. AgResearch Ltd, Invermay.

Rhodes, A.P.; Aspin, M.D. 1993. MRDC Monitor Farms - using information. Proceedings of the New Zealand Grassland Association 55: 23-26. 